\title{
KONSEP DESAIN MEJA KOMPUTER WARNET GAME ONLINE
}

\author{
Christin Mardiana \\ Staf Pengajar Program Studi Desain Produk, Jurusan Desain \\ Institut Teknologi Adhi Tama Surabaya \\ Rizky Gustevan Rayes \\ Mahasiswa Program Studi Desain Produk, Jurusan Desain \\ Institut Teknologi Adhi Tama Surabaya \\ e-mail: kikiboyyy@gmail.com
}

\begin{abstract}
Abstrak
Di Surabaya, ada banyak warnet game online, salah satunya yang akan dipakai untuk studi kasus adalah warnet 3 kingdom. Untuk masalah yang terjadi di warnet 3 kingdom ini, belum tersedianya cup holder.belum tersedia sandaran kaki.belum ada tempat headphone. belum tersedianya hand dryer.belum usb hub.belum tersedianya tempat tisu. Dan kabel manajemennya berantakan. Selain di 3kingdom, peneliti juga memakai warnet xgate untuk studi kasus. Permasalahan yang terjadi pun sesuai dengan 3kingdom. Untuk 3 kingdom beralamat di Jalan Klampis Jaya blok A No. 29, Surabaya dan untuk Xgate beralamat di Ruko Landmark Delta, Jl. Panjang Jiwo Permai Selatan, Surabaya. Studi kasusnya sendiri melakukan observasi, wawancara adan membagikan kuisioner. Kuisioner dibagikan 15 pemain di 3kingdom dan 15 pemain di xgate. Untuk wawancaranya 5 pemain di 3kingdom dan 5 pemain di xgate. Untuk Analisisnya terdiri dari analisis kebutuhan, analisis kebutuhan ruang, analisis ergonomi dan antropometri, analisis penempatan, analisis material, analisis bentuk, analisis warna, analisis sistem, dan analisis mekanisme sambungan. Untuk konsep desain menggunakan konsep desain modern yaitu konsep yang mengutamakan efektivitas dan fungsionalitas. Untuk desain alternatif produk desain meja komputer warnet ini mempunyai 5 desain alternatif. Dan yang terakhir adalah oleh kesimpulan dan saran dari desain meja komputer warnet 3 kingdom.
\end{abstract}

Kata kunci : Desain, Game online, Meja Komputer, Warnet 3 kingdom, 
Christin Mardiana, Rizky Gustevan Rayes, Konsep Desain Meja Komputer Warnet

Game Online

\section{Abstract}

In Surabaya, there are many online gaming cafes, one of which will be used for case studies is internet Cafe 3 Kingdom. For problems in the 3 Kingdoms Internet cafe, there is no available cup holder. No footrest yet. No headphone. No place yet. No hand dryer. No USB hub. Unavailability of tissue place. And the management cable was messy. In addition to the 3kingdoms, researchers also used Xgate Cafe for case studies. The problem occurred in accordance with the 3kingdom. For 3 kingdoms located in Klampis Jaya block A No. 29 Street, Surabaya and for Xgate address at Landmark Delta, South Panjang Jiwo Permai street, Surabaya. His own case studies observe, interview and distribute the questionnaire. The questionnaire was shared 15 players in $3 k i n g d o m$ and 15 players at Xgate. For his interview 5 players in 3kingdom and 5 players at Xgate. For analysis, it consists of needs analytics, space requirement analysis, ergonomics and anthropometry analysis, placement analysis, material analysis, form analysis, color analysis, system analysis, and connection mechanism analysis. For the concept of design using modern design concept is concept that prioritizes effectiveness and functionality. For alternative design of computer desk internet cafe has 5 alternative designs. And the last is by the conclusion and suggestion of the computer Desk Design Cafe 3kingdom.

Keyword : 3Kingdom Cafe Online Games, Computer table, Design, Online Games

\section{Latar Belakang}

Game online sendiri tidak pernah lepas dari perkembangan teknologi komputer dan jaringan komputer itu sendiri, karena game tersebut mempunyai spesifikasi yang harus dimiliki komputer maupun jaringannya, untuk periferal (perangkat tambahan) komputernya sendiri terdiri dari mouse, keyboard, monitor, speaker atau headphone. Istilah game disini merupakan permainan elektronik yang menggunakan media komputer atau mesin-mesin konsol. Industri game juga sudah merambah ke berbagai negara di dunia termasuk negara-negara berkembang. Game mulai populer ke seluruh dunia dimulai dengan populernya barbagai game di Amerika pada era 70-an dan mulai berkembang ke berbagai negara di awal tahun 80-an. Di Indonesia Menurut Ligagame, game online muncul pada tahun 2001, dimulai dengan masuknya Nexia Online1. Di Surabaya sendiri, terdapat banyak warnet game online, salah satunya adalah warnet 3 kingdom, Warnet 3 kingdom beralamat di Jalan Klampis Jaya blok A No. 29 Surabaya. Warnet 3 kingdom ini mempunyai 3 tempat didalam satu komplek ruko 42 di Klampis jaya, yaitu kalangan reguler, vip, dan vvip. Untuk masalah yang terjadi di warnet 3 kingdom ini, kondisi meja komputer warnet game online yang ada sekarang sama seperti meja komputer biasa, banyak pemain yang bermain game online itu membawa minuman botol untuk diminum karena bermain game online dalam waktu lama dan botol minuman tersebut ditaruh didekat periperal komputer warnet seperti keyboard. Beberapa Pemain game online yang mengeluhkan kalau kakinya capek, karena dimeja komputer tersebut tidak ada tempat untuk bersandar. Headphone yang digunakan untuk warnet game online diletakkan dimonitor dan kabel headphonenya kurang tertata. Para pemain yang sedang bermain game online dalam waktu lama, dikondisi ruangan yang ber $\mathrm{AC}$ tersebut mengakibatkan tangan para pemain tersebut menjadi dingin dan kadang menjadi basah sehingga mengakibatkan para pemain tersebut menjadi tidak konsentrasi saat bermain game online. Banyak pemain game online yang mengeluhkan tidak terdapatnya tempat mengisi baterai terdekat dengan mejanya. 
Vol. 7, No. 2, April 2020

Berdasarkan permasalahan tersebut, peneliti ingin membuat sebuah desain meja komputer yang digunakan untuk komputer game online. Meja komputer ini dibuat untuk meminimalisir masalah-masalah yang terjadi pada warnet tersebut.

\section{Tujuan Perancangan}

Mendesain sebuah meja game komputer yang sesuai dengan kebutuhan para pemain game online saat bermain game.

\section{Metode Perancangan}

Pada penelitian ini, peneliti menggunakan mix method, yakni penelitian kualitatif dan kuantitatif. Metode kualitatif dilakukan dengan melakukan wawancara dengan narasumber terkait dengan pengembangan penelitian. Metode kuantitatif dilakukan dengan membagikan kuisoner kepada responden yaitu para pemain warnet game online terkait dengan meja komputer warnet game online.

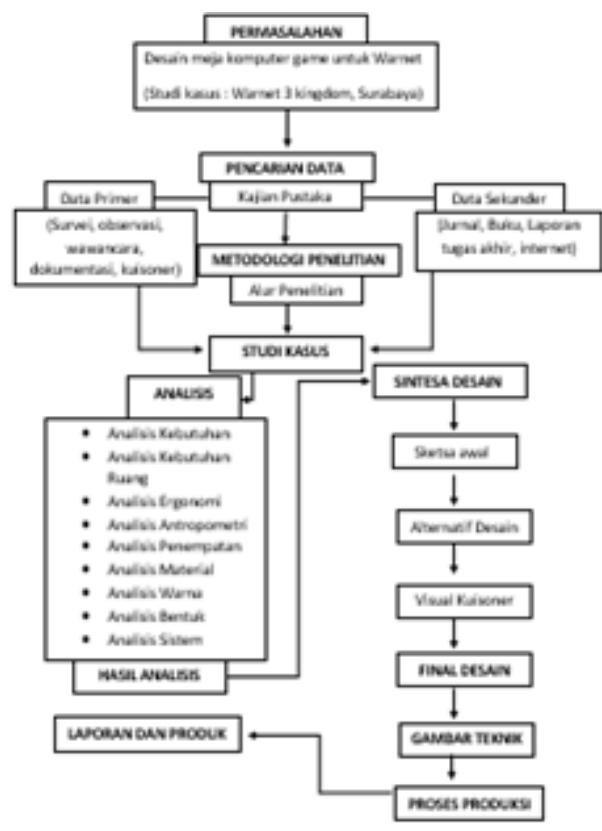

Gambar 1. Skema Penelitian

\section{Pembahasan \\ 4.1. Studi Kasus}

Studi kasus ini dilakukan oleh peneliti pada pemain game online karena penelitian ini membutuhkan informasi mengenai meja komputer yang digunakan oleh para pemain game online. Kegiatan studi kasus objek dilakukan di warnet 3kingdom dan warnet xgate yang berlokasi di Surabaya.

\subsection{Studi Observasi Aktivitas}

Pada studi observasi aktivitas ini bertujuan untuk mengetahui aktivitas dari para pemain game online mulai dari membeli billing / pembayaran hingga selesai bermain game. Dari kegiatan observasi yang dilakukan didapatkan data sebagai berikut:

Aktivitas pertama yang dilakukan oleh pemain game online yaitu Sebelum memainkan game online, para pemain ke kasir untuk membayar billing/waktu main yang ditentukan oleh para pemain. Peralatan yang digunakan adalah 1) uang

Lalu Setelah membayar billing/ waktu para pemain game online akan mencari komputer yang akan digunakan untuk bermain game online dan menyalakannya. Peralatan yang digunakan adalah 1) Kursi, 2) CPU Komputer

Saat melakukan permainan game online, pemain biasanya langsung memakai headphone saat bermain game, dan headphonenya selain untuk bermain game juga untuk berinteraksi dengan pemain lain. Peralatan yang digunakan adalah 1) Headphone Setelah bermain setengah jam sampe 1 jam player haus, dan minum botol minuman yang dibeli dari kasir. Peralatan yang digunakan adalah 1) Botol minuman

Setelah bermain selama 2-4 Jam pemain game online merasa kedinginan, dan pemain game online pun menggosokkan tangannya. Peralatan yang digunakan adalah 1) Tangan

Setelah selesai bermain game online, pemain mengeluarkan akun billingnya dan bersiap-siap untuk keluar. Peralatan 
Christin Mardiana, Rizky Gustevan Rayes, Konsep Desain Meja Komputer Warnet

Game Online

yang digunakan 1) Mouse 2) Kursi

Tabel 1. Analisis kebutuhan ruang

\subsection{Analisis Kebutuhan}

Menganalisis kebutuhan alat-alat yang digunakan berdasarkan hasil studi kasus dan observasi yang telah dilakukan kepada 10 responden yang ada di warnet game online 3 kingdom dan warnet game online Xgate yang digunakan oleh pengguna dari awal sampai akhir adalah mouse, keyboard, headphone dan mousepad. Untuk peralatan-peralatan lainnya seperti CPU dan monitor hanya digunakan saat pengguna menyalakan komputer. Untuk minuman beberapa kali digunakan oleh pengguna.

Berdasarkan hasil pengamatan dan wawancara terhadap responden dilapangan dibutuhkan beberapa tambahan seperti : 1) Menambahkan atau memperluas untuk area gerak mouse, 2) Menambah port usb 3), Menambah tempat taruh minuman atau barang lainnya, 4) Menambah tempat tisu, 5) Menambahkan sandaran kaki, 6) Menambahkan hand dryer, 7) Menambahkan tempat meletakkan headphone, 8) Alat untuk merapikan kabel manajemen.

Maka dari data diatas dapat disimpulkan bahwa kebutuhan bermain komputer game online yang digunakan oleh responden adalah : 1) Meja komputer, 2) Mouse, 3) Keyboard, 4) Monitor, 5)CPU, 6)Headphone, 7) Tempat Minuman, 8) Mousepad, 9)Port USB, 10) Penghangat tangan, 11) Sandaran kaki, 12) Tempat tisu, 13) Alat untuk merapikan kabel manajemen.

\subsection{Analisis Kebutuhan Ruang}

Menganalisis kebutuhan ruang berdasarkan kebutuhan alat-alat bermain komputer game online yang digunakan oleh responden dua warnet game online di Surabaya :

\begin{tabular}{|c|c|c|c|}
\hline No & Peralatan & Dimensi & Jumlah \\
\hline 1 & $\begin{array}{l}\text { Meja } \\
\text { komputer } \\
\text { wamet } \\
\text { 3kingdom }\end{array}$ & $\begin{array}{c}\text { L: }: 70 \mathrm{~cm} \mathrm{x} \\
\text { P: } 100 \mathrm{~cm} \mathrm{x} \\
T: 73 \mathrm{~cm}\end{array}$ & 1 \\
\hline 2 & $\begin{array}{l}\text { Meja } \\
\text { komputer } \\
\text { warnet xgate }\end{array}$ & $\begin{array}{c}\text { L: } 80 \mathrm{~cm} \mathrm{x} \\
\text { P: } 104 \mathrm{~cm} \mathrm{x} \\
T: 76 \mathrm{~cm}\end{array}$ & 1 \\
\hline 3 & Mouse & $\begin{array}{c}\mathrm{T}: 12 \mathrm{~cm} \mathrm{x} \\
\mathrm{L}: 6 \mathrm{~cm} \mathrm{x} \\
\mathrm{D}: 3 \mathrm{~cm}\end{array}$ & 1 \\
\hline 4 & Keyboard & $\begin{array}{c}\text { P: } 44 \mathrm{~cm} \mathrm{x} \\
\text { L: } 14 \mathrm{~cm} \mathrm{x} \\
\text { D: } 4 \mathrm{~cm}\end{array}$ & 1 \\
\hline 5 & $\begin{array}{l}\text { Monitor } \\
\text { komputer } \\
\text { warnet } \\
\text { 3kingdom }\end{array}$ & $\begin{array}{l}\text { L: } 41 \mathrm{~cm} x \\
T: 71 \mathrm{~cm} \mathrm{x} \\
D: 20 \mathrm{~cm}\end{array}$ & 1 \\
\hline 6 & $\begin{array}{l}\text { Monitor } \\
\text { komputer } \\
\text { warnet xgate }\end{array}$ & $\begin{array}{c}\mathrm{L}: 62 \mathrm{~cm} \mathrm{x} \\
T: 58 \mathrm{~cm} \mathrm{x} \\
D: 27 \mathrm{~cm} \\
\end{array}$ & 1 \\
\hline 7 & Headphone & $\begin{array}{l}\text { T: } 17 \mathrm{~cm} \mathrm{x} \\
\mathrm{L}: 8 \mathrm{~cm} \mathrm{x} \\
\mathrm{D}: 18 \mathrm{~cm}\end{array}$ & 1 \\
\hline 8 & $\mathrm{CPU}$ & $\begin{array}{c}\text { T: } 54 \mathrm{~cm} \mathrm{x} \\
\mathrm{L}: 24 \mathrm{~cm} \mathrm{x} \\
\text { D: } 56 \mathrm{~cm}\end{array}$ & 1 \\
\hline 9 & $\begin{array}{c}\text { Kursi } \\
\text { komputer }\end{array}$ & $\begin{array}{l}\mathrm{L}: 69 \mathrm{~cm} \mathrm{x} \\
\text { D: } 70 \mathrm{~cm} \mathrm{x} \\
\text { T: } 124 \mathrm{~cm}\end{array}$ & 1 \\
\hline 10 & Minuman & $\begin{array}{c}\text { L: } 6 \mathrm{~cm} \mathrm{x} \\
\mathrm{T}: 23 \mathrm{~cm} \mathrm{x} \\
\mathrm{D}: 6 \mathrm{~cm}\end{array}$ & 1 \\
\hline 11 & Mousepad & $\begin{array}{l}\text { L: } 80 \mathrm{~cm} \mathrm{x} \\
\text { P: } 35 \mathrm{~cm} \mathrm{x} \\
\text { D: } 0.3 \mathrm{~cm}\end{array}$ & 1 \\
\hline
\end{tabular}

Keterangan :

a. T : Tinggi

b. L : Lebar

c. P : Panjang

d. D : Diameter

Kesimpulannya adalah kebutuhan ruang untuk desain meja komputer game online yang dipakai sesuai dengan tabel diatas adalah semuanya kecuali meja komputer xgate dan monitor komputer xgate. 
Vol. 7, No. 2, April 2020

\subsection{Analisis Penempatan}

Berdasarkan penempatan, maka desain meja komputer untuk warnet game online terbagi menjadi beberapa bagian, yaitu tempat untuk meletakkan minuman, tempat untuk headphone, tempat untuk hand dryer, untuk tempat untuk CPU, tempat untuk port usb, tempat untuk sandaran kaki, tempat untuk tempat tisu, dan tempat alat untuk merapikan kabel manajemen.
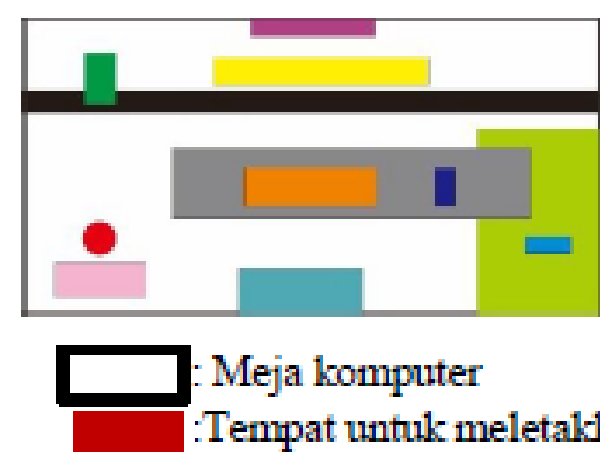

Meja komputer

Tempat untuk meletakkan minuman / cup folder

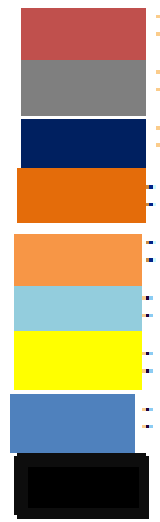

: Keyboard

: Mousepad

Mouse

Tempat untuk CPU

Tempat untuk headphone

Tempat untuk hand dryer

Monitor

Tempat untuk port usb

Tempat untuk Sandaran

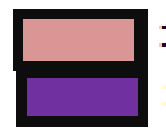

: Tempat tisu

:Tempat alat untuk kabel manajemen

Gambar 2. Analisis Penempatan

\subsection{Analisis Material}

Analisis material dilakukan agar dapat menemukan material yang sesuai dengan produk meja komputer warnet game online. Berikut adalah kebutuhan material yang digunakan untuk meja komputer warnet game online adalah 1) Bahan material yang tidak menyusut, 2) Mudah dalam pemotongan, 3) Proses produksi mudah, 4) Tahan air, 5) Mudah dibentuk, 6) Finishing lebih mudah, 7) Harga material murah, 8) Material tahan lama.

Kesimpulan berikut ini didapat dari analisis yang telah dilakukan oleh peneliti serta data yang didapat untuk pemilihan material adalah berbahan kayu MDF.

\subsection{Analisis Finishing}

Analisis finishing dilakukan agar dapat menemukan finishing yang tepat untuk disesuaikan dengan material pada produk. Berikut adalah kebutuhan finishing yang dibuat untuk Desain meja komputer warnet game online adalah 1) Tahan air, 2) Banyak pilihan warna dan tekstur, 3) Relatif murah. Berdasarkan hasil analisis yang telah dilakukan peneliti, finishing yang sesuai untuk untuk Desain meja komputer warnet game online adalah HPL (High Pressure Laminate).

\subsection{Analisis Bentuk}

Analisis bentuk digunakan untuk memilih jenis bentuk yang akan digunakan pada produk. Bentuk yang akan digunakan untuk Desain meja komputer warnet game online adalah persegi panjang dan lingkaran.

\subsection{Analisis Sistem}

Analisis sistem dilakukan agar dapat menemukan sistem yang sesuai untuk digunakan pada pada produk. Berikut adalah sistem yang ditujukan untuk desain meja komputer warnet game online adalah 1) Mudah dipindahkan, 2) Mempersingkat waktu penataan, 3) Dapat digabung dengan lainnya. 
Christin Mardiana, Rizky Gustevan Rayes, Konsep Desain Meja Komputer Warnet

Game Online

Berdasarkan kesimpulan yang dilakukan oleh peneliti, maka sistem yang akan digunakan adalah sistem modular. Dimana sistem ini mudah dipindahkan, multifungsi, fleksibel, mudah dikemas. Sistem ini sangat sesuai untuk menyesuaikan perabot, kedalam keadaan layout yang berbeda-beda

\subsection{Analisis Warna}

Analisis warna dilakukan untuk menentukan warna yang akan digunakan pada Desain meja komputer warnet game online. Berikut adalah warna yang digunakan untuk Meja komputer warnet game online adalah 1) Warna putih, karena warna putih akan nampak bercahaya, netral dan bisa dikombinasikan dengan warna apapun. 2) Warna hitam, karena warna hitam bisa dimaknakan bahwa mereka tunduk kepada Tuhan. Disisi lain, warna hitam berarti sangat kuat, pemakainya akan terlihat jahat dan menyeramkan. 3) Warna cokelat, karena warna bumi dan alam. Menunjukkan utilitas, membumi, warna kayu dan kekayaan alam yang berlimpah.

\subsection{Spesifikasi Desain}

Dari analisis yang telah dilakukan, maka dapat disesuaikan dengan spesifikasi desain yang akan digunakan pada produk adalah sebagai berikut.

\section{A. Kebutuhan}

1. Meja komputer

2. CPU

3. Monitor

4. Mouse

5. Mousepad

6. Keyboard

7. Headphone

8. Tempat Minum

9. Port USB

10. Penghangat tangan

11. Sandaran kaki

12. Tempat tisu

13. Tempat untuk mengatur kabel manajemen

\section{B. Dimensi}

1. $103 \mathrm{~cm} \times 74 \mathrm{~cm} \times 73 \mathrm{~cm}$

\section{Material}

1. Meja komputer menggunakan kayu MDF

2. Finishing menggunakan finishing HPL

\section{Warna}

1. Warna hitam sebagai warna utama

\section{E. Bentuk}

1. Kombinasi Persegi dan lingkaran

\section{F. Sistem}

1. Sistem Modular

\subsection{Konsep Desain}

Konsep desain yang nantinya diaplikasikan pada produk desain meja komputer game online adalah konsep desain modern, Konsep desain modern itu menggambarkan konsep desain yang mengutamakan pada efektivitas dan fungsionalitas, konsep ini juga konsep desain yang mewakili hidup modern yang simple dan menarik. Konsep ini dipilih karena desain meja komputer game online ini nantinya lebih mengutamakan segi efektivitas dan fungsionalitas meja komputer tersebut, dimana artinya desain meja komputer ini bisa memberikan manfaat atau salah satu cara untuk penempatan komputer beserta aksesoris-aksesoris yang akan dipasang dengan area yang terbatas.

\subsection{Alternatif Desain}

1. Alternatif Desain 1

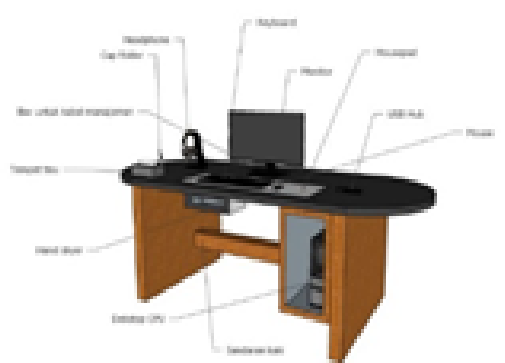

Gambar 3. Alternatif Desain 1 
Vol. 7, No. 2, April 2020

\section{Alternatif Desain 2}

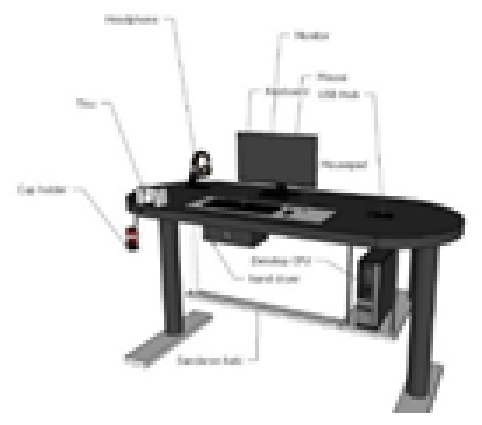

Gambar 4. Alternatif Desain 2

\section{Alternatif Desain 3}

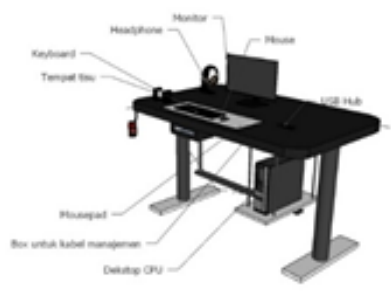

Gambar 5. Alternatif Desain 3

\section{Alternatif Desain 4}

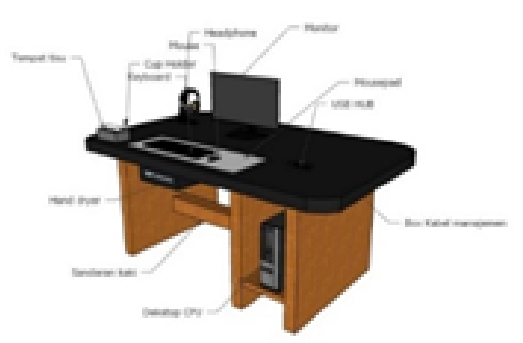

Gambar 6. Alternatif Desain 4

\section{Alternatif Desain 5}

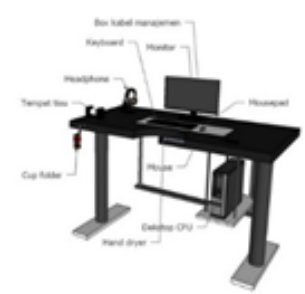

Gambar 7. Alternatif Desain 5
V. Kesimpulan dan Saran

\subsection{Kesimpulan}

Desain meja komputer warnet game online bertujuan mempermudah gamer / pengunjung warnet game online saat akan menggunakan komputer di meja komputer. Dengan adanya tempat meletakkan minuman dan adanya tempat sandaran kaki akan membuat gamer / pengunjung warnet game online akan nyaman saat mengoperasikan komputer warnet game online ini.

Selain itu produk ini memiliki fungsi lain yaitu penghangat tangan yang sangat berguna bagi gamer atau pengunjung warnet game online saat bermain game online dalam waktu lama, dan tangannya mengalami keringat atau basah.

\subsection{Saran}

Desain meja komputer warnet game online ini mempunyai beberapa kelemahan. Diantaranya material yang dirasa kurang kuat dan tidak mempunyai tempat penyimpanan. Sehingga apabila ada penelitian selanjutnya yang membahas desain meja komputer game online peneliti berharap agar penelitian selanjutnya memperhatikan material yang digunakan dan menyediakan tempat penyimpanan 
Christin Mardiana, Rizky Gustevan Rayes, Konsep Desain Meja Komputer Warnet

Game Online

\section{Daftar Pustaka}

Akmal, Imelda., Anasatsya, Erlina,.\& Safitri, Gita. 2009. Panduan lengkap menata rumah. Jakarta : PT Gramedia Pustaka Utama

Irawan, Bambang., Tamara, Priscilla. 2013. Dasar-Dasar Desain. Jakarta : Griya Kreasi

Kamaluddin, Yusuf Arif., \& Marisa, Lucky. 2009. Cara Cepat Menghitung Kebutuhan Materi. Jakarta : Transmedia Pustaka

Malik, Kendal. 2016. Kapita Selekta Desain. Padang : LPPMPP ISI Padangpanjang. Nugroho, Sarwo. 2015. Manajemen Warna dan Desain. Yogyakarta : CV Andi offset

Rachmatia, Anita., \& Dwimirnani, Putri. 2010. Menata dapur minimalis. Bogor : PT Penebar Swadaya

Soedwaji, Jusuf. 2012. Pengantar metodologi penelitian. Jakarta : Mitra Wacana Media

Wibowo, Ibnu Teguh. 2013. Belajar Desain Grafis. Yogyakarta : Buku Pintar

Yunus, Aryanto. 2012. 173 Meja dan Kursi. Bogor : Griya Kreasi 